\title{
Antiulcerogenic Activity of Eight Chromatographic Fractions of Ethyl Acetate Leaf Extracts of Securidaca longepedunculata fres. (Polygalaceae) and Luffa cylindrica (L.) Roem. (Cucurbitaceae)
}

\author{
ABOLANLE AZEEZ ABIDEEN KAYODE ${ }^{1 *}$, MUBO ADEOLA SONIBARE ${ }^{2}$ \\ and JONES OLANREWAJU MOODY²
}

'Phytomedicine Research, Drug Discovery and Development Laboratory, Department of Biochemistry, Benjamin S. Carson (Snr) School of Medicine, Babcock University, llishan-Remo, Ogun State Nigeria. ${ }^{2}$ Department of Pharmacognosy, Faculty of Pharmacy, University of Ibadan, Ibadan, Oyo State Nigeria.

*Corresponding author E-mail: bolakayot@gmail.com

http://dx.doi.org/10.13005/ojc/360113

(Received: April 17, 2019; Accepted: February 22, 2020)

\section{ABSTRACT}

Securidaca longepedunculata (SL) and Luffa cylindrica (LC) leaf extracts have been shown to exhibit significant antiulcer effect on ethanol-induced gastric lesions. This study examined the antiulcerogenic effect of chromatographic fractions of ethyl acetate extracts of the selected plants. The ethyl acetate extracts of (SL) and (LC) were fractionated using Vacuum Liquid Chromatography (VLC). Antiulcer screening was carried out on the eight chromatographic fractions obtained. The fractionation afforded four fractions (A, B, C and D) each for Securidaca longepedunculata and Luffa cylindrica. Twenty groups of 5 rats each were treated with 50 and $100 \mathrm{mg} / \mathrm{kg} \mathrm{b.w}$ of LCA1-LCD2 and SLA1-SLD2, respectively. Fraction B of LC (LCB2, $100 \mathrm{mg} / \mathrm{kg} \mathrm{b.w)} \mathrm{gave} \mathrm{the} \mathrm{highest}$ percentage of ulcer inhibition (94.9\%) while fraction D of SL (SLD2, $100 \mathrm{mg} / \mathrm{kg} \mathrm{b.w)} \mathrm{showed} \mathrm{the}$ highest percentage protection (92.3\%), against ethanol-induced gastric ulcer. Chromatographic fractions of the ethyl acetate extracts may also possess antiulcerogenic property.

Keywords: Antiulcerogenic, Chromatographic fractions, Securidaca longepedunculata,
Luffa cylindrica.

\section{INTRODUCTION}

Peptic ulcers are deep gastrointestinal erosion disorder that involves the entire mucosal thickness, penetrating the muscular mucosa ${ }^{1,2}$. Peptic ulcers represent one of the most important diseases of the digestive system and a medico-social problem of global economic importance, the latter due to its broad geographical distribution, as well as high incidence, morbidity and drug consumption.
It is estimated that at some time in their life nearly $20 \%$ of all people may suffer from peptic ulcers, caused by factors such as stress, diet, smoking, alcohol and certain types of drugs ${ }^{3,4}$. The drugs currently used in the treatment of gastric ulcers are antacids, anticholinergics, proton pump inhibitors and $\mathrm{H} 2$-receptor antagonists. However, there are innumerable adverse effects caused by these allopathic medicines ${ }^{4,5}$, indicating the need for more effective and safer anti-gastric ulcer agents with less

This is an Open Access article licensed under a Creative Commons license: Attribution 4.0 International (CC- BY). Published by Oriental Scientific Publishing Company @ 2018

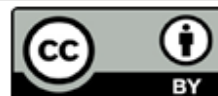


side effects. In this context, metabolites derived from plants used in traditional medicine have provided an important basis for the discovery and development of modern therapeutic drugs ${ }^{4,6}$.

Securidaca longepedunculata Fres. (Polygalaceae) (Fig. 1), called violet tree (English), is a small plant, with sweetly smelling and bright coloured flowers. The plant is widespread throughout tropical Africa. In many parts of Africa, the plant is employed in traditional medicine principally for its psychotropic properties ${ }^{7,8}$. Other uses include treatment of rheumatic conditions, many inflammatory conditions, treatment of several sexually transmitted diseases, fever, headache, constipation, stomach pain, malaria, skin infections, peptic ulcer disease and also as sexual enhancer,8,9,10,11. The pulverized root is also a functional agent in the control of pest during grain storage $\mathrm{e}^{8,12,13}$.

Luffa cylindrica (L.) Roem. (Cucurbitaceae) (Fig. 2), known as sponge gourd or bath sponge, has been researched on for its anti-inflammatory, fungusdestroying, analgesic and sedation, anti-myocardial ischemia, antiulcer, anti-asthma and expectorant effects among others ${ }^{14}$. Luffa cylindrica has been found to be a unique vegetable which also belongs to a family of cucumber and marrow and also known as a vegetable sponge or sponge gourd ${ }^{15,16}$. In addition to being used as edible vegetable, Luffa also finds a wide application in packing medium, shoes mats, sound proof linings, bath sponges, utensil cleaning sponges, adsorbent for removal of heavy metal [such as Nickel, Lead, Chromium, Copper, etc] in waste water, and immobilization matrix for plant, algae, bacteria and yeast ${ }^{16,17}$. However, in spite of the wide medicinal application of these two plants, there is scarcity of information in literature on their application as antiulcer agents. Therefore, the aim of this study was to investigate the antiulcer activity of the chromatographic fractions of the ethyl acetate extracts of the selected medicinal plants.

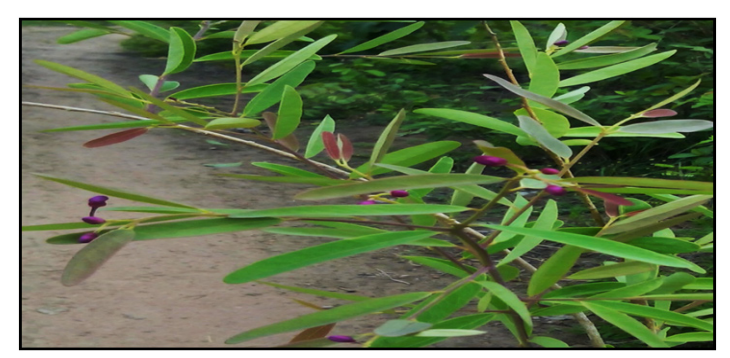

Fig. 1. Securidaca longepedunculata Source: Adesiyan Village, Ido Local Government Area (LGA), Oyo State, Nigeria (Collected January, 2014)

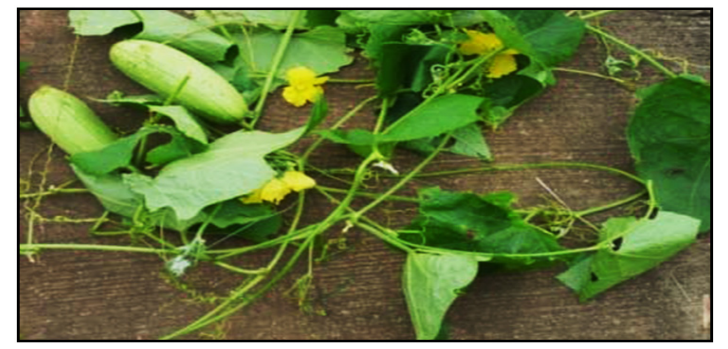

Fig. 2. Leaves of Luffa cylindrica Source: Igboloye, Ota, Ado-Odo Ota (LGA) Ogun State, Nigeria (Collected January, 2014)

\section{MATERIALS AND METHODS}

\section{Vacuum Liquid Chromatography}

Vacuum Liquid Chromatography of ethyl acetate leaf extract of Securidaca longepedunculata

The ethyl acetate leaf extract $(91.37 \mathrm{~g})$ of Securidaca longepedunculata was prepared into slurry with ethyl acetate and adsorbed onto silica gel. This was allowed to dry. A vacuum column chromatography cup and a vacuum pump were used for the chromatographic set up. The column chromatography was performed on silica gel (TLC grade, without the binder) (Merck; Germany) and successively eluted with increasing polarities of solvents starting from $100 \% \mathrm{n}$-hexane, $\mathrm{n}$-hexane/ dichloromethane (DCM), DCM/ethyl acetate (EtoAC) to $100 \%$ methanol $(\mathrm{MeOH})$. Fractions were collected and pooled based on their TLC profiles and the pooled fractions were concentrated. Antiulcer screening was thereafter carried out on each of the pooled fraction.

\section{Vacuum Liquid Chromatography of ethyl acetate leaf extract of Luffa cylindrica}

The ethyl acetate leaf extract ( $79.87 \mathrm{~g})$ Luffa cylindrica was prepared into slurry with ethyl acetate and adsorbed onto silica gel. This was allowed to dry. A vacuum column chromatography cup and a vacuum pump were used for the chromatographic set up. The column chromatography was performed on silica gel (TLC grade, without the binder) (Merck; Germany) and successively eluted with increasing polarities of solvents starting from $100 \% \mathrm{n}$-hexane, n-hexane/DCM, DCM/EtoAC to $100 \% \mathrm{MeOH}$. Fractions were collected and pooled based on their TLC profiles and the pooled fractions were concentrated. Antiulcer screening was thereafter carried out on each of the pooled fraction. 


\section{Thin Layer Chromatography}

Analytical thin layer chromatography (TLC) was conducted with Si gel 60 F254 plates (10 $\times 5$ and $5 \times 1$ Merch, Germany).

\section{Experimental Animals for Bioassays}

One hundred albino Wistar rats of both sexes with average weight $130 \mathrm{~g}$ were used for the experiments. These animals were purchased from the animal house of the Department of Physiology, University of Ibadan, Oyo State, Nigeria. The rats were kept in wooden cages with wooden shaven beddings to prevent coprophagy. The male rats were separated from the female rats to prevent copulation. The rats were supplied water ad libitum and fed standard feed. They were kept under standard conditions of temperature and humidity. The animals were acclimatized for a period of one week in the animal house of the Department of Physiology, University of Ibadan, Oyo State, Nigeria. The ethical standard for animal handling and treatment was followed.

\section{Animal Treatment}

One hundred rats was divided into 20 groups of 5 rats each with average weight $130 \mathrm{gram}$. The treatment groups comprised:

Normal Control: Normal saline treated animals Positive Control (Ulcer Group): Animals challenged with Absolute Ethanol Negative Control (Cimetidine Group): 50 \& $100 \mathrm{mg} /$ $\mathrm{kg}$ b. $w$ cimetidine treated animals and ulcerated SL Chromatographic Fractions Pretreated animals prior to Ulcer Induction

SLA1 \& SLA2: 50 \& $100 \mathrm{mg} / \mathrm{kg}$ b.w extract

SLB1 \& SLB2: 50 \& $100 \mathrm{mg} / \mathrm{kg}$ b.w extract

SLC1 \& SLC2: 50 \& $100 \mathrm{mg} / \mathrm{kg}$ b.w extract

SLD1 \& SLD2: 50 \& $100 \mathrm{mg} / \mathrm{kg}$ b.w extract

LC Chromatographic Fractions Pretreated animals prior to Ulcer Induction

LCA1 \& LCA2: 50 \& $100 \mathrm{mg} / \mathrm{kg}$ b.w extract

LCB1 \& LCB2: 50 \& $100 \mathrm{mg} / \mathrm{kg}$ b.w extract

LCC1 \& LCC2: 50 \& $100 \mathrm{mg} / \mathrm{kg}$ b.w extract

LCD1 \& LCD2: 50 \& $100 \mathrm{mg} / \mathrm{kg}$ b.w extract

\section{Experimental Protocol for Ulceration}

Wistar rats were fasted overnight but given water ad libitum. The chromatographic fractions and cimetidine were given to the animals orally.
Fifty minutes later, $1 \mathrm{~mL}$ of absolute ethanol was administered orally. The animals were sacrificed after $1 \mathrm{~h}$ and their stomachs excised and opened along the greater curvature, rinsed with $1.15 \% \mathrm{KCl}$ and ulcer scoring/severity grading was done.

\section{Quantification of Ulceration}

Ulceration index which is the extent of ulceration in the rat and percentage inhibition was done and calculated according to the methods described by Kayode et al., ${ }^{8}$ and Lee et al., ${ }^{18}$

\section{RESULTS}

The fractions obtained from the Vacuum Liquid Chromatography (VLC) of SL and LC are illustrated in Table 1 and 2. The VLC of LC afforded four fractions with the yield $(\mathrm{g})$ in the following order $L C D>$ LCC > LCB > LCA. Similarly, the VLC of SL gave four fractions with the yield in this pattern SLD > SLC > SLB > SLA (Table 2). Groups treated with LCB1 and LCB2 (from Fraction LCB) gave the highest percentage ulcer inhibition of $92.3 \%$ and $94.9 \%$, respectively. The LCC1 has the lowest percentage ulcer inhibition (Table 3). Animals pretreated with SLD1 and SLD2 showed the highest percentage gastric ulcer inhibition (87.2\% and $92.3 \%$ ) among the groups pretreated with the chromatographic fractions of Securidaca longepedunculata (Table 4). The lowest of the SL treated groups was the SLA1 with $64.8 \%$ (Table 4). The standard antiulcer drug, cimetidine, used as negative control revealed $64.1 \%$ and $71.8 \%$ for 50 and $100 \mathrm{mg} /$ $\mathrm{kg} \mathrm{b.w}$, respectively (Table 3 and 4).

Table 1: Vacuum Liquid Chromatography of Ethyl acetate Extract Luffa cylindrica $(79.87 \mathrm{~g})$

\begin{tabular}{lccc}
\hline VLC Pooled & & \\
\multicolumn{1}{l}{ Fractions (Weight g) } & Solvent Mixture & Ratio Per 500 mL \\
\hline LCA 1-5 & $(7.92)$ & Hexane/DCM & $70: 30$ \\
LCB 6-12 & $(10.88)$ & DCM/Hexane & $90: 10$ \\
LCC 13-18 & $(15.60)$ & DCM/Ethyl acetate & $60: 40$ \\
LCD 19-34 & $(40.87)$ & Ethyl acetate/Methanol & $70: 30$ \\
\hline
\end{tabular}

Table 2: Vacuum Liquid Chromatography of Ethyl acetate Extract Securidaca longepedunculata $(91.37 \mathrm{~g})$

\begin{tabular}{lccc}
\hline $\begin{array}{l}\text { VLC Pooled } \\
\text { Fractions (Weight g) }\end{array}$ & Solvent Mixture & Ratio Per 500 mL \\
\hline SLA 1-4 & $(7.78)$ & Hexane & $80: 20$ \\
SLB 5-12 & $(8.73)$ & DCM/Hexane & $90: 10$ \\
SLC 13-18 & $(21.29)$ & Ethyl acetate/DCM & $60: 40$ \\
SLD 19-32 & $(29.53)$ & Ethyl acetate/Methanol & $70: 30$ \\
\hline
\end{tabular}


Table 3: Effect of VLC fractions Luffa cylindrica on absolute ethanol-induced gastric ulcer

\begin{tabular}{ccc}
\hline Experimental Group & (Weight mg/kg b.w) & Inhibition (\%) \\
\hline LCA1 & $(50)$ & 61.5 \\
LCA2 & $(100)$ & 92.3 \\
LCB1 & $(50)$ & 92.3 \\
LCB2 & $(100)$ & 94.9 \\
LCC1 & $(50)$ & 38.5 \\
LCC2 & $(100)$ & 46.2 \\
LCD1 & $(50)$ & 46.2 \\
LCD2 & $(100)$ & 61.5 \\
Ethanol & $(1 \mathrm{~mL})$ & 0.0 \\
Cimetidine & $(50)$ & 64.1 \\
Cimetidine & $(100)$ & 71.8 \\
Normal control & $(1 \mathrm{~mL}$ Normal Saline) & - \\
\hline
\end{tabular}

Table 4: Effect of VLC fractions Securidaca longepedunculata on absolute ethanol-induced gastric ulcer

\begin{tabular}{ccc}
\hline Experimental Group & (weight $\mathrm{mg} / \mathrm{kg} \mathrm{b.} \mathrm{w)}$ & Inhibition (\%) \\
\hline SLA1 & $(50)$ & 64.8 \\
SLA2 & $(100)$ & 71.8 \\
SLB1 & $(50)$ & 82.1 \\
SLB2 & $(100)$ & 92.3 \\
SLC1 & $(50)$ & 71.8 \\
SLC2 & $(100)$ & 76.9 \\
SLD1 & $(50)$ & 87.2 \\
SLD2 & $(100)$ & 92.3 \\
Ethanol & $(1 \mathrm{~mL})$ & 0.0 \\
Cimetidine & $(50)$ & 64.1 \\
Cimetidine & $(100)$ & 71.8 \\
Normal control & $(1 \mathrm{~mL}$ Normal Saline) & - \\
\hline
\end{tabular}

\section{DISCUSSION}

Induction of gastric ulcers using ethanol are commonly used for the assessment of gastroprotection ${ }^{19}$. Oral administration of absolute ethanol solution to the control group clearly produced the necessary mucosal injury. Absolute ethanol solution ( $1 \mathrm{~mL} / 130 \mathrm{~g} \mathrm{b.w}$ ) induced gastric ulcer in all treated animals and this agrees with reports in other previous studies ${ }^{8,18,20}$. Pretreatment with 50 $\mathrm{mg} / \mathrm{kg}$ and $100 \mathrm{mg} / \mathrm{kg}$ of LCA1 - LCD2 and SLA1 SLD2 caused significant ulcer inhibition in varying degrees. The significant percentage inhibition of ulceration shown by the groups pretreated with the chromatographic fractions of Luffa cylindrica and Securidaca longepedunculata suggests that these treatment agents have gastro protective properties $8,19,20,21,22$. The present study demonstrates that the VLC fractions of the ethyl acetate leaf extracts of Securidaca longepedunculata and Luffa cylindrica are possible potent gastro protective and antiulcer agents against ethanol-induced gastric ulcer. The obtained results show that these fractions induced significant antiulcer effect in ethanol-induced gastric lesions. We speculate that the gastro protective and antiulcer effects of these fractions from the selected plants could be partly attributed to free radical scavenging property of the plant, inhibition of gastric acidity and strengthening of the gastric mucosal barrier through antioxidant enzyme induction. In summary, our data suggest that the antiulcer effect of these plants ${ }^{8}$ appears to be retained in the chromatographic fractions of the ethyl acetate extracts. The data obtained for the effect of treatment of the chromatographic fractions on ethanol-induced ulcer in rats provide a scientific platform for the validation of the folkloric and public use of these plants in ulcer disease treatment and management. The data given may correlate with the results obtained for other indigenous medicinal plants used traditionally for gastric ulcer treatment ${ }^{23,24,25,26,27,28,29}$. The results obtained from this study could influence the development of a new drug for gastric ulcer treatment.

\section{ACKNOWLEDGMENT}

The authors would like to thank Prof. O. Sonibare and Prof. O. Aiyelagbe of the Department of Chemistry, Faculty of Science, University of Ibadan, Ibadan, Oyo State, Nigeria for the equipment and laboratory space provided to carry out this work.

\section{Conflict of interest}

The authors declare that there are no conflicts of interest.

\section{REFERENCES}

1. Tarnawski, A. S. Cellular and Molecular Mechanisms of Gastrointestinal Ulcer Healing. Digest. Dis. Sci., 2005, 50, 24-33.

2. Heloina, S. F.; Jacqueline, A. L.; José, M. B.; Petrônio, F. A.; Maria, C. O. C.; Marcelo, D.
M.; Anderson, L. F.; Ana Beatriz, A. A.; Alba Regina, M. S.; Margareth, F. F. M.; L. M. B. Gastric and Duodenal Antiulcer Activity of Alkaloids: A Review. Molecules., 2008, 13, 3198-3223. 
3. Bucciarelli, A.; Minetti, A.; Milczakowskyg, C.; Skliar, M. Evaluation of Gastroprotective Activity and Acute Toxicity of Solidago chilensis Meyen (Asteraceae). Pharm. Biol., 2010, 48, 1025-1030.

4. Sánchez-Mendoza, M. E.; Reyes-Ramírez, A.; Antonio, L. C.; Jiménez, L. M.; RodríguezSilverio, J.; Arrieta, J. Bioassay-Guided Isolation of an Anti-Ulcer Compound, Tagitinin C, from Tithonia diversifolia: Role of Nitric Oxide, Prostaglandins and Sulfhydryls. Molecules., 2011, 16, 665-674.

5. Babu, T. H.; Manjulatha, K.; Kumar, G.S.; Hymavathi, A.; Tiwari, A.K.; Purohit, M.; Rao, J.M.; Babu, K.S. Gastroprotective Flavonoid Constituents from Oroxylum indicum Vent. Bioorg. Med. Chem. Lett., 2010, 20, 117-120.

6. Santin, J.R.; Lemos, M.; Klein, L.C., Jr.; Niero, R.; de Andrade, S.F. Antiulcer Effects of Achyrocline satureoides (Lam.) DC (Asteraceae) (Marcela), A folk Medicine Plant, in different Experimental Models. J. Ethnopharmacol., 2010, 130, 334-339.

7. Winkleman, M.; Dobkin de Rios, M. Psychoactive properties of Kung Bushmen Medicinal Plants. Journal of Psychoactive Drugs., 1989, 21, 51-59.

8. Kayode, A. A. A.; Sonibare, M. A.; Moody, J.O. Antiulcer Activities of Securidaca longepedunculata Fres. (Polygalaceae) and Luffa cylindrica (L.) Roem. (Cucurbitaceae) Leaf Extracts. Nig. J. Nat. Prod and Med., 2015, 19, 85-91.

9. Assi, L. A.; Guinko, S. Plants Used in Traditional Medicine in West Africa. HoffmanLaRoche Ltd., Switzerland., 1991, 106.

10. Iwu, M.M. Handbook of African Medicinal Plants, CRC Press, Boca Raton, Fl., 1993, 57.

11. Mongalo, N. 1.; MacGaw, L. J.; Finnie, J. F.; Van Staden J. Securidaca longepedunculata Fresen (Polygalaceae): A review of its Ethnomedicinal Uses, Phytochemistry, Pharmacological Properties and Toxicology. Journal of Ethnopharmacology., 2015, 165, 215-26.

12. Belmain, S. R.; Neal, G. E.; Ray, D. E.; Golob, P. Insecticidal and Vertebrate Toxicity Associated with Ethnobotanicals Used as
Post-Harvest Protectants in Ghana. Food and Chemical Toxicology., 2001, 39, 287-291.

13. Boeke, S. J.; Van Loon, J. J. A.; Van Hus, A.; Kossou, D. K.; Dicke, M. The Use of Plant Materials to Protect Stored Leguminous Seeds Against Seed Beetles: A Review Wageningen University Papers, Backhuys Publishers, Leiden, NL., 2001, 108.

14. Partap, S.; Kumar, A.; Sharma, N. K.; Jha, K. K. Luffa cylindrica: An Important Medicinal Plant. Journal Natural Products and Plant Resources., 2012, 2(1), 127-134.

15. Oboh, I. O.; Aluyor, E. O. Luffa Cylindrica An Emerging Cash Crop. African Journal of Agricultural Research., 2009, 4, 684-688.

16. Azeez, M. A.; Bello, O. S.; Adedeji, A. O. Traditional and medicinal uses of Luffa cylindrica: A Review. Journal of Medicinal Plants Studies., 2013, 1(5), 102-111.

17. Demir, H.; Top, A.; Balkose, D.; Ulku, S. Dye adsorption behavior of Luffa cylindrica fibers. Journal of Hazardous Materials., 2008, 153, 389-394.

18. Lee, E. B.; Kim, O. J.; Kang, S. S. Jeong, C. Araloside $\mathrm{A}$, an Antiulcer Constituent from the Root Bark of Aralia elata. Biological and Pharmaceutical Bulletin., 2005, 28(3), 523-6.

19. Gülçin, I.; Küfrevioglu, O. I.; Oktay, M.; Büyükokuroglu, M. E. Antioxidant, Antimicrobial, Antiulcer and Analgesic Activities of Nettle (Urtica dioica L.). J Ethnopharmacol., 2004, 90(2-3), 205-15.

20. Kayode, A. A. A.; Kayode, O. T.; Odetola, A. A. Anti-ulcerogenic Activity of Two Extracts of Parquetina nigrescens and their Effects on Mucosal antioxidants Defense System on Ethanol- Induced Ulcer in Rats. Research Journal Medicinal Plant., 2009, 3, 102-108.

21. Hiruma-Lima, C. A.; Calvo, T. R.; Rodrigues, C. M.; Andrade, F. D.; Vilegas, W.; Brito, A. R. Antiulcerogenic activity of Alchornea castaneaefolia: Effects on Somatostatin, Gastrin and Prostaglandin. Journal of Ethnopharmacology., 2006, 104, 215-224.

22. Bhattacharya, S.; Chaudhuri, S. R.; Chattopadhyay, S.; Bandyopadhyay, S. K. Healing Properties of Some Indian Medicinal Plants against Indomethacin-Induced Gastric Ulceration of Rats. Journal of Clinical Biochemistry and Nutrition., 2007, 41, 106-114. 
23. Dias, P. C.; Foglio, M. A.; Possenti, A.; Nogueira, D. C. F.; Ernesto de Carvalho, J. Antiulcerogenic Activity of Crude Ethanol Extract and Some Fractions Obtained from Aerial Parts of Artemisia annua L. Phytother. Res., 2001, 15, 670-675.

24. Andradea, S. F.; Antoniollia, D.; Comunelloa, E.; Cardosob, L. G. V.; Carvalhob, J. C.T.; Bastos, J. K. Antiulcerogenic Activity of Crude Extract, Fractions and Populnoic Acid Isolated from Austroplenckia populnea (Celastraceae). Z. Naturforsch., 2006, 61c, 329-333.

25. Klein, L. C.; Gandolfi, R. B.; Santin, J. R.; Lemos, M.; Filho, V. C.; Faloni de Andrade, S. Antiulcerogenic Activity of Extract, Fractions, and Some Compounds Obtained from Polygala cyparissias St. Hillaire \& Moquin (Polygalaceae) Naunyn-Schmied Arch Pharmacol., 2010, 381, 121-126.

26. Lemos, L. M. S.; Martins, T. B.; Tanajura, G. H.; Gazoni, V. F.; Bonaldo, J.; Strada, C. L.; Gabriel da Silva, M.; Dall’Oglio, L. U.; Teixeira de Sousa, P.; Martins, D. T. Evaluation of
Antiulcer Activity of Chromanone Fraction from Calophyllum brasiliesnse Camb. Journal of Ethnopharmacology., 2012, 141, 432- 439.

27. Boligon, A. A.; Borba de Freitas, R.; Faccim de Bruma, T.; Waczuk, E. P.; Klimaczewski, C. V.; Silva de Ávila, D.; Athayde, M. L.; Bauermann, L. Antiulcerogenic Activity of Scutia buxifolia on Gastric Ulcers Induced by Ethanol in Rats. Acta PharmaceuticaSinica B., 2014, 4(5), 358-367.

28. Mota da Silva, L.; Boeing, T.; Somensi, L. B.; Cury, B. J.; Steimbach, V. M.P.; Silveria, A. C.; Niero, R.; Filho, V. C.; Santin, J. R.; Faloni de Andrade, S. Evidence of Gastric Ulcer Healing Activity of Maytenus robusta Reissek: In vitro and In vivo Studies. Journal ofEthnopharmacology., 2015, 175, 75-85.

29. Sabiu, S.; Garuba, T.; Sunmonu, T.; Ajani, E.; Sulyman, A.; Nurain, I.; Balogun, A. Indomethacin-induced Gastric Ulceration in Rats: Protective Roles of Spondias mombin and Ficus exasperate. Toxicology Reports., 2015, 2, 261-267. 